\title{
BRPKM
}

Buletin Riset Psikologi dan Kesehatan Mental

http://e-journal.unair.ac.id/index.php/BRPKM

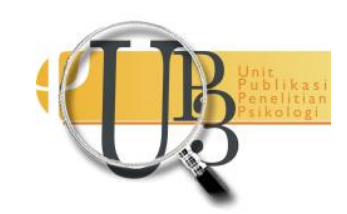

ARTIKEL PENELITIAN

\section{Psychological Well-being Korban Pasca Traumatic Event Kejahatan dengan Kekerasan}

\author{
LATIEVA SONIA SALMANY \& NURUL HARTINI*
}

Departemen Psikologi Klinis dan Kesehatan Mental, Fakultas Psikologi Universitas Airlangga

\begin{abstract}
ABSTRAK
Korban kejahatan dengan kekerasan rentan mendapatkan stigma negatif dan diskriminasi dari lingkungan sosial yang akan berdampak pada psychological well-being-nya. Penelitian ini menggunakan metode penelitian kualitatif dengan pendekatan studi kasus dengan teknik penggalian data wawancara dan observasi dan dianalisis dengan teknik analisis data alir miles dan huberman. Jumlah partisipan pada penelitian ini berjumlah lima orang dimana seluruh partisipan merupakan korban kejahatan dengan kekerasan yang sedang berada di tahap perkembangan beranjak dewasa. Masing masing memiliki dimensi dalam psychological well-being terdampak sebagai respon dari kejadian traumatis. Namun, beberapa partisipan sudah menjadi lebih adaptif. Di sisi lain, ditemukan bahwa pada beberapa partisipan, dimensi personal growth bisa berperan sebagai faktor protekti. Sebagian besar partisipan tidak menunjukkan gejala gangguan kesehatan mental yang lebih serius seperti PTSD. Namun, ada diantaranya yang menunjukkan gejala dissosiatif yaitu derealisation dan yang lainnya mengalami gejala depresi seperti adanya keinginan untuk bunuh diri dan menyakiti diri sendiri.
\end{abstract}

Kata kunci: kejadian traumatis, kesejahteraan psikologis

\begin{abstract}
Victims of crimes with violence are vulnerable to negative stigma and discrimination from the society which will have an impact on their psychological well-being. This research is using qualitative methods, a case study approach, extracting data from interviews and observations and analyzed using data analysis techniques of flow miles and Huberman. There are five subjects which is victims of violent crimes who were in the developing stage of emerging adulthood. Each of them has dimensions in the affected psychological well-being as a response to the traumatic event. However, some subjects have become more adaptive. On the other hand, it was found that in some subjects, the personal growth dimension could act as a protective factor. Most of the subjects showed no symptoms of a more serious mental health disorder such as PTSD. However, some of them show dissociative symptoms, derealisation, and another have depressive symptoms such as suicidal thoughts and self-harm.
\end{abstract}

Keywords: psychological well-being, traumatic event

Buletin Penelitian Psikologi dan Kesehatan Mental (BRPKM), 2021, Vol. 1(1), 481-496

*Alamat korespondensi: Fakultas Psikologi Universitas Airlangga, Kampus B Universitas Airlangga Jalan

Airlangga 4-6 Surabaya 60286. Surel: nurul.hartini@psikologi.unair.ac.id 


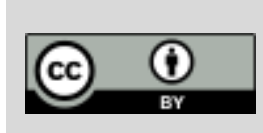

Naskah ini merupakan naskah dengan akses terbuka dibawah ketentuan the Creative Common Attribution License (CC-BY-4.0) (http://creativecommons.org/licenses/by/4.0), sehingga penggunaan, distribusi, reproduksi dalam media apapun atas artikel ini tidak dibatasi, selama sumber aslinya disitir dengan baik.

\section{PEN D A H U L U A N}

Rasa aman adalah hak setiap manusia. Untuk menjamin hak ini negara menyebutkan dalam UUD Republik Indonesia 1945 Pasal 28G ayat 1 yang berbunyi bahwa setiap orang berhak atas perlindungan diri pribadi, keluarga, kehormatan, martabat, dan harta benda yang di bawah kekuasaannya, serta berhak atas rasa aman dan perlindungan dari ancaman ketakutan untuk berbuat atau tidak berbuat sesuatu yang merupakan hak asasi. Rasa aman yang dimiliki masyarakat dapat berubah menjadi ketakutan akibat adanya kriminalitas atau kejahatan di lingkungan tempat tinggalnya. Kejahatan merupakan salah satu fenomena sosial yang normal terjadi di masyarakat (Runturambi, 2017). Di Indonesia sendiri tindak kejahatan sudah diatur pada beberapa pasal pada KUHP, contohnya pada pasal 365 KUHP tentang pencurian dan pasal 351 KUHP tentang penganiayaan (KUHP RI, 1992). Presentase penduduk yang menjadi korban kejahatan pada tahun 2017 meningkat dari 1,08\% menjadi 1,11\% pada tahun 2018 (Statistik, 2019). Untuk kasus kekerasan sendiri, tercatat pada data simfoni PPA sejak tanggal 1 Januari 2020 hingga 21 Agustus 2020 terdapat kasus kekerasan terhadap perempuan dewasa sebanyak 3605 kasus dengan total 3649 korban. Kementerian Pemberdayaan Perempuan dan Perlindungan Anak bahkan mengkhawatirkan adanya kasus-kasus lain yang tidak terlaporkan selama pandemi COVID-19 (Kementrian Pemberdayaan Perempuan dan Perlindungan Anak, 2020).Menjadi korban kejahatan dengan kekerasan bukanlah sebuah posisi yang mudah. Hal ini dikarenakan korban juga rawan mendapatkan stigma dan penolakan dari masyarakat.

Berdasarkan studi kasus yang dilakukan di Tuban, Jawa Timur, ditemukan bahwa partisipan penelitian yang merupakan korban kekerasan seksual kerap mendapatkan stigma dan penolakan baik secara verbal maupun non-verbal. Masyarakat di sekitar keberadaan korban juga menunjukkan sikap diskriminatif. Hal ini bisa menyebabkan korban sulit untuk kembali membaur dengan masyarakat (Astuti, 2016). Adanya perlakuan diskriminatif dari lingkungan tempat tinggal seseorang memiliki korelasi negatif terhadap psychological well-being seseorang. (Schmitt et al., 2014)Menurut penelitian tentang subjective well-being individu korban kejahatan pencurian dan penculikan yang disusun oleh (Nathania et al., 2017), partisipan pada penelitian ini mengaku merasa sedih pada tindak kejahatan yang pertama kali terjadi karena barang yang hilang merupakan benda berharga dan merasa takut akan terjadinya kejadian kedua. Partisipan kedua merasa trauma terhadap kejadian yang dialaminya. Hal ini merupakan dampak negatif pada komponen afeksi dalam subjective well-being. Dampak negatif dengan frekuensi yang tinggi mengindikasikan bahwa subjective well-being individu juga rendah. Akibatnya, efektifitas keberlangsungan hidup seseorang akan terganggu (Hanggoro, 2015; Nathania et al., 2017). Seperti yang dicatat oleh Creamer, Burgess, Buckingham, dan Pattison (1993) trauma yang dihasilkan murni dari kejahatan manusia lebih sulit bagi korban untuk dipahami dan diproses secara kognitif daripada yang dihasilkan dari kejadian traumatis seperti peperangan atau bencana alam.

Dalam memahami keadaan seorang korban pasca kejadian traumatis, psychological well-being perlu untuk diteliti. Hal ini berkaitan dengan makna seseorang terhadap traumatic or stressful event yang dialaminya mempengaruhi bagaimana dia akan merespon kejadian tersebut (Aldwin, 2007). Studi dari

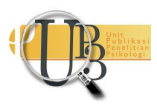


Crystal L. (2012 dalam Park et al., 2012) menunjukkan bahwa kejadian traumatis berpengaruh negatif terhadap global meaning. Global meaning adalah bagaimana seseorang memandang dan memahami dirinya, lingkungan sekitarnya, dan perilakunya. Global meaning mempengaruhi kepercayaan, tujuan, dan perasaan partisipantif seseorang terhadap makna kehidupannya. Makna partisipantif akan kehidupan pada global meaning dapat menuntun seseorang untuk memiliki perasaan positif terhadap dirinya sendiri dan memunculkan motivasi untuk mencapai tujuan dan keidealan dalam hidup. Hal inilah yang menyebabkan global meaning memiliki hubungan yang kuat terhadap psychological wellbeing (Park \& Gutierrez, 2013).

Berdasarkan paparan penjelasan diatas, melakukan penelitian terhadap psychological well-being korban pasca kejahatan sengan kekerasan perlu untuk dilakukan. Di Indonesia sendiri, penelitian pasca kejadian traumatis yang berfokus pada kejahatan lebih banyak mengambil sumber dari luar negeri. Hal ini disebabkan karena penelitian berbasis post-traumatic di Indonesia lebih banyak berfokus pada kejadian bencana alam (Hamidah et al., 2018). Oleh sebab itu peneliti tertarik untuk mengkaji lebih dalam tentang kejadian traumatis dengan meninjau psychological well-being korban khususnya korban kejahatan dengan kekerasan.

\section{Psychological well being}

Psychological well-being adalah enam dimensi konsep teoritis yang menjelaskan tentang bagaimana seseorang dapat berfungsi secara positif. Seperti yang dirangkum oleh Huppert psychological well-being adalah tentang bagaimana kehidupan berjalan dengan baik (Huppert, 2009). Oleh karena itu, orangorang dengan nilai psychological well-being yang tinggi merasa bahagia, mampu, didukung dengan baik, puas dengan kehidupan, dan sebagainya. Psychological well-being terkait dengan realisasi potensi intim, dan terdiri dari beberapa parameter seperti hubungan positif dan penerimaan diri (Machado et al., 2019). Studi terhadap well-being biasanya digunakan untuk analisa hasil atau variabel dependen sebuah fenomena, juga sebagai anteseden atau prediktornya. Selain itu, kajian terhadap well-being juga digunakan untuk melihat faktor protektif seseorang. Masa Perkembangan Beranjak Dewasa

Pada masa perkembangan beranjak dewasa, kemampuan berpikir individu dan kemampuan adaptasi dalam menghadapi trauma dan stres yang dialaminya merupakan hal yang penting karena trauma yang dialami pada masa anak-anak juga bisa mempengaruhi hingga masa remaja dan dewasa. Keinginan untuk bunuh diri dan self-harm atau bentuk melukai diri lainnya adalah dampak serius yang diasosiasikan dengan permasalahan kesehatan mental yang terjadi pada masa perkembangan remaja dan beranjak dewasa (Macleod \& Brownlie, 2014). Selain itu, mengalami kejadian traumatis merupakan salah satu faktor prediktor kecemasan dan depresi pada masa perkembangan beranjak dewasa. Beberapa peneliti berpendapat bahwa dampak psikologis yang terjadi tidak secara langsung diakibatkan oleh kejadian yang dialami, melainkan bagaimana individu secara partisipan memaknai kejadian tersebut (Allen, 2001). Dalam hal ini, stress negatif dan trauma dapat mengancam self-esteem, mengurangi self-efficacy, menyalahkan diri sendiri dan kepercayaan disfungsional lainnya yang berhubungan dengan gejala kecemasan dan depresi (Riggs \& Han, 2009).

Pada penelitian yang oleh (Overstreet et al., 2016) dengan sampel mahasiswa baru Virginia Commonwealth University (VCU) ditemukan bahwa 81,8\% dari partisipan pernah mengalami potentially traumatic event (PTE) semasa hidupnya dan 39\% diantaranya melaporkan paling tidak satu kali interpersonal trauma, seperti kekerasan fisik, kekerasan seksual, atau perilaku seksual yang tidak diinginkan lainnya. Selain itu $8.7 \%$ dari partisipan melaporkan sebanyak empat atau lebih pengalaman 
PTE dengan kategori yang berbeda. Jenis kelamin perempuan dan penyimpangan kelompok secara konsisten dikaitkan dengan dengan paparan PTE dan adanya gejala psikopatologi. Riwayat paparan PTE interpersonal juga diasosiasikan dengan peningkatan penggunaan alkohol, distres terkait trauma, gejala depresif, dan gejala kecemasan (Overstreet et al., 2016).

\section{Traumatic Event}

Dalam DSM-V, Paparan terhadap potentially traumatic event (PTE) (American Psychiatric Association, 2013) diasosiasikan dengan peningkatan tingkat gangguan mental dan secara signifikan berkontribusi terhadap resiko post-traumatic stress disorder (PTSD) dan gangguan stress lainnya (Overstreet et al., 2016). Setelah pengalaman traumatis, beberapa orang akan mengalami kesulitan ketika menghadapi kenyataan. Reaksi yang umum terjadi adalah merasa cemas dan depresi ringan, memiliki pikiran dan ingatan yang menyedihkan tentang kejadian traumatis, sulit tidur, dan merasa sangat waspada terhadap tanda-tanda bahaya (Ursano, 2012). Reaksi-reaksi ini dapat berlangsung selama beberapa hari, minggu, atau bahkan berbulan-bulan setelah kejadian traumatis. Walaupun untuk beberapa orang kemudian hal itu berangsur-angsur memudar tanpa sangat berdampak pada kemampuan korban untuk melanjutkan fungsi normal sehari-hari mereka, beberapa orang bisa jadi gagal untuk beradaptasi dan mengembangkan hal ini menjadi gangguan stress akibat trauma (Galatzer-Levy et al., 2012).

\section{E T O D E}

\section{Desain Penelitian}

Pada penelitian ini, penulis menggunakan metode penelitian kualitatif. Pendekatan ini dipilih karena dapat memberikan gambaran suatu fenomena secara menyeluruh serta menghasilkan data deskriptif (Poerwandari, 2007). Pada penelitian kualitatif data yang dihasilkan berupa data deskriptif kata-kata tertulis atau lisan dari hasil pengamatan (Bowker et al., 1978). Pendekatan kualitatif berfokus pada bagaimana seorang individu memperoleh makna atas kehidupannya dan bukan hasil perlakuan atau manipulasi dari suatu variabel (Gunawan, 2014). Penelitian ini dilakukan menggunakan tipe penelitian studi kasus. Penelitian studi kasus adalah pendekatan penelitian dengan menggunakan beberapa metode teknik pengumpulan data dan analisis (Willig, 2013).

\section{Partisipan}

Partisipan pada penelitian ini adalah partisipan utama dan significant other partisipan utama. Partisipan utama merupakan seseorang yang mengalami kejadian traumatis kejahatan dengan kekerasan itu sendiri, sedangkan significant other adalah keluarga atau kerabat, teman, atau orang terdekat yang mengetahui secara langsung kondisi partisipan utama setelah mengalami kejadian traumatis kejahatan dengan kekerasan untuk melakukan teknik pemantaban kredibilitas dan menggali data secara lebih dalam. Partisipan utama penelitian dipilih berdasarkan kriteria: (a) warga negara indonesia, (b) berusia 18-25 tahun, (c) pernah paling tidak mengalami atau mendapatkan satu kali tindak kejahatan dengan kekerasan (kekerasan fisik, kekerasan seksual, dan pencurian dengan kekerasan).

Krtiteria-kriteria tersebut disebar dengan poster elektronik yang menyertakan link google form di sosial media. Google form yang disebar sudah menyertakan informed consent untuk mengikuti penelitian. Dengan mengisi google form tersebut, partisipan yang memenuhi kriteria dan bersedia untuk mengikuti penelitian akan dihubungi secara personal untuk proses penelitian lebih lanjut yaitu observasi dan wawancara. Peneliti mendapatkan 103 responden yang seusai dengan kriteria, namun hanya 23 diantaranya yang bersedia untuk melanjutkan pada sesi wawancara. Untuk mempersempit lagi,

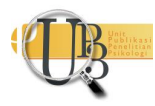


partisipan yang mendapatkan luka, melaporkan kejadian yang dialami kepada pihak berwajib, dan menggunakan jasa dokter atau psikolog akibat kejadian traumatis yang dialami lebih diutamakan. Dari sini peneliti hanya tersisa 10 partisipan yang selanjutnya dihubungi kembali dan mendapatkan 3 partisipan yang mengonfirmasi ketersediaanya sebagai partisipan wawancara dan bersedia melakukan wawancara via video call. Di sisi lain, tidak ada korban pencurian dengan kekerasan yang memenuhi kriteria diatas. Oleh sebab itu, peneliti memilih 2 orang yang merupakan korban pencurian dengan kekerasan yang bersedia untuk melakukan wawancara via video call. Selanjutnya, peneliti memberikan informed consent dan meminta tanda tangan partisipan apabila menyetujui keterlibatannya dengan penelitian yang dilakukan. Terakhir, peneliti menetapkan jadwal dengan partisipan dan melakukan wawancara di waktu yang telah disepakati.

\section{Teknik Pengumpulan Data}

Teknik pengambilan data yang digunakan adalah wawancara dan observasi yang nantinya akan diorganisasikan menjadi bentuk transkrip dan dianalisis dengan metode data analisis Miles \& Huberman (Ridder et al., 2014), kemudian ditarik kesimpulan dari hasil analisis tersebut. Sesuai dengan jenis penelitian yang merupakan penelitian kualitatif, maka teknik pengumpulan data yang digunakan oleh peneliti adalah semi-structured Interview, dan observasi. Bersamaan dengan adanya pandemi global COVID-19, pemerintah membatasi adanya aktifitas sosial. Oleh sebab itu, kemungkinan besar proses pengambilan data akan dilaksanakan secara daring.

Prinsip-prinsip etis dari informed consent, anonimitas dan kerahasiaan dipatuhi sepanjang proses pengumpulan dan analisis data. Partisipasi sepenuhnya bersifat sukarela dan responden diberikan informasi adanya hak yang akan mereka dapatkan dan bahwa mereka diperbolehkan untuk mundur pada setiap tahap proses penelitian. Karena penelitian berbasis wawancara memiliki sifat pribadi, peserta diberi tahu tentang hak mereka untuk memilih untuk tidak menjawab pertanyaan yang mereka tidak ingin jawab. Semua peserta dirujuk dengan nama samaran atau inisial yang sudah disepakati.

\section{Analisis Data}

Penelitian studi kasus ini menggunakan komponen metode analisis data alir Miles dan Huberman (Ridder et al., 2014). Miles dan Huberman (1994) melihat analisis data sebagai aliran aktifitas yang terdiri dari tiga komponen, yaitu (1) data condensation yaitu proses dimana data yang sudah didapatkan diseleksi, disederhanakan, menciptakan abstrak, dan/atau mengubah data yang berupa data mentah seperti catatan lapangan, verbatim, dokumen dan data lainnya menjadi data yang lebih kuat, (2)data display yaitu tahap dimana data yang sudah diolah dikelola kembali agar dapat dibentuk kesimpulannya dan diberikan tindakan, dan (3) conclusion drawing or verification yaitu tahap dimana peneliti menganalisis dengan menginterpretasikan data dan membentuk kesimpulan (Ridder et al., 2014). Teknik pemantapan kredibilitas wawancara yang digunakan oleh peneliti adalah triangulasi yang merupakan teknik kredibilitas data diuji dengan cara mengecek data kepada sumber yang sama dengan teknik yang berbeda. Hal ini dikarenakan data diperoleh dengan wawancara, lalu dicek dengan observasi dan dokumentasi. 


\section{HAS IL P E N ELIT IAN}

\section{$\underline{\text { Traumatic Event Korban Kejahatan dengan Kekerasan }}$}

\section{Partisipan VT}

Partisipan mengalami kekerasan seksual berupa pembegalan payudara. Kejadian ini terjadi saat partisipan sedang mencari makan dengan berjalan kaki bersama salah satu temannya. Tempat kejadian kejahatan merupakan pinggir jalan dimana daaerah tersebut ramai dengan orang yang sedang melakukan aktifitas. Partisipan tidak mengatakan langsung bagian tubuh yang disentuh oleh pelaku, tetapi partisipan menunjukkan melalui gestur yang menunjukkan ke bagian dada. Respon awal partisipan adalah blank, tidak bisa teriak, dan tiba tiba terdiam. Setelah itu menoleh ke arah pelaku, tetapi pelaku sudah melaju menggunakan sepedah motor sehingga partisipan sudah tidak bisa melakukan apa-apa. Partisipan memaknai kejadian ini sebagai pelajaran agar selalu waspada dimanapun karena tempat ramai ataupun sepi, dan bagaimana pakaian yang digunakan sudah tidak menjamin keamanannya lagi. Partisipan juga memilih untuk tidak jalan kaki sendirian lagi, apabila ada keperluan untuk bepergian, partisipan lebih memilih untuk ditemani atau jika diharuskan bepergian sendiri partisipan akan menggunakan kendaraan. Dampak dari kejadian ini adalah berubahnya pandangan partisipan terhadap diri sendiri, orang lain, dan lingkungannya. Partisipan masih merasa aneh dengan dirinya selama dua bulan setelah kejadian. Selain kejadian kekerasan yang dialami, partisipan juga memiliki riwayat kekerasan fisik yang dilakukan oleh anggota keluarganya. Kekerasan yang dialami partisipan mengakibatkan luka dibawah area mata. Setelah kejadian partisipan dapat memahami alasan terjadinya tindak kekerasan tersebut dan memaafkan ibunya. Kejadian ini tidak berdampak secara berkelanjutan selain partisipan yang memiliki pandangan untuk tidak melakukan hal tersebut ke anaknya kelak.

\section{Partisipan AP}

Partisipan AP mengalami pencurian dengan kekerasan saat masih ada di bangku SMP. Kerugian akibat kejadian ini adalah hilangnya sepeda yang biasanya digunakan oleh partisipan dan luka-luka ringan. Kronologis kejadiannya bermula saat ada dua orang yang menghampiri partisipan dan menanyakan tempat persewaan konsol game PS 4. Kedua orang tersebut meminta partisipan untuk mengantarkan ke tempat tujuan dan menyarankan partisipan agar dibonceng oleh pelaku. Setelah pelaku meminta untuk beristirahat, pelaku seperti mencekik partisipan dengan menarik menarik kerah baju korban dan mendorongnya hingga jatuh. Partisipan ditinggalkan di tempat sepi dan pelaku membawa kabur sepeda milik partisipan AP. Partisipan tidak melakukan tindakan perlawanan apapun karena masih kelas 3 SMP dan merasa takut dengan orang yang lebih dewasa. Partisipan juga merasa bahwa teriak bukanlah pilihan yang tepat melihat kondisi sekitar yang sepi dan bingung harus berbuat apa. Setelah mengalami kejadian tersebut partisipan merasa takut. Partisipan mendeskripsikan bahwa badannya panas dingin dan memiliki ketakutan untuk pulang karena takut dimarahi oleh orang tuanya.

Partisipan memaknai kejadian tersebut sebagai rasa kemanusiaan yang disalahgunakan. Kejadian tersebut sudah terencana karena pencuri tersebut mampu menciptakan kondisi yang sesuai dengan aksinya. Ada sisi dimana partisipan merasa bersalah karena mengikuti perkataan pelaku. Dampak dari kejadian yang dialami partisipan AP adalah perubahan pandangan terhadap orang lain. Partisipan menjadi trauma, kurang percaya dengan orang lain, dan menjadi lebih tegas atas benda kepemilikannya.

\section{Partisipan NS}

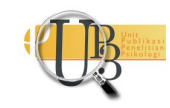


Kejadian pertama yang dialami partisipan NS adalah kekerasan seksual saat duduk di bangku SD. Perbuatan tersebut dilakukan oleh salah satu wali murid di sekolahnya. Saat itu partisipan belum memahami bahwa hal itu adalah sesuatu yang salah dan merupakan tindakan kekerasan seksual. Kejadian kedua adalah tindakan kekerasan fisik yang dilakukan oleh guru SMP partisipan NS. Guru tersebut memaksa partisipan untuk menonton porno bersama dan saat partisipan menolak, Guru tersebut melukai partisipan dengan membenturkan kepala partisipan ke dinding. Akibatnya partisipan mendapatkan luka jahitan di area kepala dan sempat dilarikan ke rumah sakit.

Respon partisipan NS pada saat kejadian adalah freezing, takut dan setelah berbulan bulan partisipan masih meragukan kejadian yang dialami, juga merasa bahwa hal itu tidak nyata. Partisipan menunjukkan adanya denial terhadap kejadian kekerasan fisik yang dialaminya dengan menolak dan segera menghentikan pikiran tentang kejadian tersebut. Setelah mengalami kejadian saat SMP, partisipan mengalami susah bicara. Partisipan banyak menghabiskan waktu dengan bengong dan menjadi ragu untuk melakukan sesuatu.

Kejadian ketiga merupakan tindakan pencurian dengan kekerasan yang dialami partisipan NS dalam 12 bulan terakhir. Kejadian bermula saat partisipan sedang membawa goni berisi sembako yang diberikan oleh kampusnya. Saat berada di sebuah gang kecil, dua orang pengendara motor mengambil goni yang sedang dibawa oleh partisipan. Pelaku juga sempat meremas dada korban saat melakukan aksinya. Setelah mengalami kejadian pencurian dengan kekerasan respon awal dari partisipan adalah shock. Setelah itu partisipan mencari motor yang tadi melakukan tindakan tersebut. Partisipan juga bertanyatanya akan kebenaran kejadian tersebut. Setelah dua hari pasca kejadian timbul luka lebam, sejak saat itu partisipan menyadari bahwa apa yang dialaminya adalah suatu hal yang nyata

\section{Partisipan DD}

Kejadian yang dialami partisipan DD adalah pencurian dengan kekerasan yang menyebabkan kerugian berupa gawai milik partisipan. Awalnya partisipan bersama kedua temannya sedang berada di sebuah taman yang agak jauh dari rumahnya dengan keadaan taman yang tidak terlalu ramai. Pelaku meminjam gawai partisipan untuk digunakan merekam video, tidak lama pelaku menodongkan senjata tajam ke arah perut partisipan dan memukul partisipan. Respon awal partisipan adalah freezing saat pisau sudah mendekati tubuh partisipan. Partisipan sempat menangis karena takut. Hal ini menyebabkan partisipan sempat tidak bemain lagi selama dua minggu. Berdasarkan teman partisipan yang juga mengalami kejadian tersebut, partisipan menjadi paranoid dan takut bermain sepeda lagi. Dampak jangka panjangnya, partisipan menjadi agak takut apabila berada di lingkungan baru dan sepi.

\section{Partisipan KR}

Kejadian pertama merupakan pemaksaan melakukan kegiatan seksual dan ancaman bunuh diri dengan menggunakan senjata tajam. Saat itu, pasangan partisipan mengajak partisipan untuk makan di luar. Awalnya partisipan sudah berencana untuk memutuskan untuk mengakhiri hubungan dengan pasangan karena merasa bahwa pasangannya bersifat toxic, manipulatif dan memaksa untuk melakukan kegiatan seksual. Namun, pasangannya mengancam untuk melakukan bunuh diri apabila partisipan bersikeras untuk mengakhiri hubungan mereka.

Kejadian kedua adalah tindak kekerasan seksual yang berupa pemaksaan melakukan hubungan seksual. Awalnya partisipan diajak makan oleh pasangannya. Namun, pasangannya mengajak partisipan kerumah untuk mengambil barang yang tertinggal. Sesampainya di rumah, partisipan didorong ke sofa, 
dengan tangan yang dipegangi oleh pasangannya. Lalu pasangannya memaksa untuk melakukan hubungan seksual karena menganggap partisipan sudah tidak perawan. Respon partisipan pada saat itu blank atau freezing sebelum pada akhirnya melakukan perlawanan dengan menendang pasangannya. Respon trauma yang ditunjukkan oleh partisipan KR secara behavioral adalah terlibat dalam hubungan yang berbahaya atau tidak aman sebagai hukuman kedirinya sendiri. Selain itu partisipan juga menyakiti diri sendiri dan memiliki pikiran untuk bunuh diri. Partisipan pernah menangis karena teringat tentang trauma yang dialaminya saat berada di situasi yang serupa. Selain kejadian kejadian tersebut, partisipan juga pernah mengalami beberapa tindakan pelecehan seksual. Partisipan juga pernah mengalami ancaman pembunuhan dengan senjata tajam yang dilakukan oleh salah satu anggota keluarganya. Namun, partisipan sudah dapat memahami dan menerima alasan kejadian itu bisa terjadi. Sehingga partisipan sudah tidak merasa dendam sama sekali.

\section{Psychological well-being Korban Kejahatan dengan Kekerasan}

\section{Autonomy}

Sebagai seorang korban kekerasan seksual, partisipan VT tidak ingin menceritakan kejadian yang dialaminya kepada siapapun. Hal ini dikarenakan partisipan tidak ingin dipandang negatif seperti "ih anak ini udah pernah dipegang" atau sebagai seseorang yang sudah tidak benar di mata orang lain. Berbeda dengan partisipan VT, partisipan NS melihat dirinya sebagai seseorang yang tidak bisa diterima oleh orang lain. Partisipan memiliki determinasi diri dan pandangan yang kuat untuk hidup sendiri dan tidak bisa hidup dengan orang lain. Partisipan berpendapat bahwa hal itu tidak akan menghambat bahkan mempermudah keberlangsungan hidupnya. Berbeda dengan partisipan VT, partisipan KR cenderung sudah tidak memedulikan omongan negatif dari orang lain yang mengarah kepadanya. Partisipan juga tidak berusaha untuk menyangkal omongan negatif tersebut. Partisipan merasa bahwa hidupnya tidak sepenting itu sampai harus melakukan klarifikasi apabila ada omongan negatif terhadap dirinya. Di satu sisi, berdasarkan significant other partisipan KR, dengan adanya pandangan negatif terhadap partisipan KR, partisipan semakin menunjukkan bahwa dirinya negatif. Menurut partisipan AP, dia tidak terganggu ketika ada ada orang yang berpikiran negatif terhadap dirinya. Hal itu dikarenakan setiap orang memiliki prinsip yang berbeda dan orang lain tidak mengetahui alasan dari perilakunya. Dalam aspek kemandirian, partisipan DD, KR dan NM menunjukkan bahwa dirinya sudah mampu untuk hidup mandiri tidak bergantung dengan orang lain.

\section{Environmental Mastery}

Setelah mengalami kekerasan seksual di jalan, pandangan partisipan VT terhadap lingkungannya menjadi berubah. Sebelumnya, partisipan mengaku santai untuk bepergian meskipun harus sendirian, tetapi sekarang partisipan memiliki rasa takut dan sebisa mungkin ditemani oleh orang lain. Apabila partisipan diharuskan untuk bepergian sendiri, solusi yang dipilih adalah menggunakan kendaraan, tidak dengan jalan kaki, dan memilih jalan sepi karena pada saat kejadian suasananya sedang ramai. Semenjak kejadian itu juga partisipan belum pernah kembali ke jalan tempat kejadian perkara. Adanya perubahan pandangan partisipan terhadap lingkungannya juga dialami oleh korban pencurian dengan kekerasan yaitu partisipan DD. Setelah kejadian partisipan DD merasa takut apabila berada di tempat yang asing dan sepi. Akhirnya partisipan dan teman temannya sempat tidak bermain dan hanya bermain di daerah yang dekat saja. Namun, partisipan DD sudah menyadari itu dan menjadi lebih waspada. Partisipan juga menyadari bahwa memilih teman merupakan hal yang diperlukan karena teman akan membentuk dan mempengaruhi seseorang. Selain itu penting untuk mengetahui kapasitas diri sendiri. Berbeda dengan partisipan VT, setelah kejadian partisipan AP masih melewati daerah tempat terjadinya perkara. Alasannya adalah agar bisa bertemu dengan pencuri sepedanya.

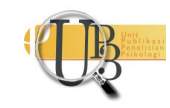


Berdasarkan keterangan dari significant other partisipan KR, lingkungan pertemanan partisipan KR sebenarnya mendukung untuk terjadinya kekerasan seksual yang dialami oleh partisipan. Setelah mengalami kejadian tersebut, partisipan tidak ingin bertemu dengan pelaku, tetapi hal itu tidak bisa dihindari karena partisipan masih berada dalam lingkungan pertemanan yang sama. Namun semenjak kuliah, partisipan sudah berhasil lepas dari lingkungan pertemanan tersebut dan bertemu dengan lingkungan pertemanan saat ini. Di sisi lain, ketika peneliti menanyakan bagaimana partisipan KR menciptakan lingkungan yang baik untuk kesehatan mentalnya, partisipan mengaku tidak mengetahui bagaimana caranya. Alasannya karena partisipan merasa dimanapun dia berada kondisi kesehatan mentalnya akan tetap sama karena hanya dirinya yang dapat membuat kesehatan mentalnya menjadi lebih baik.

Hal ini sangat berbeda dengan pendapat partisipan NS. Untuk menjaga kesehatan mentalnya partisipan menyatakan bahwa peer group merupakan salah satu sarananya. Dengan adanya peer group, partisipan bisa mengerjakan beberapa kegiatan bersama sama dan saling menanyakan kabar satu sama lain, serta bertukar pikiran dan perasaan. Dengan bertukar pikiran dan perasaan partisipan NS lebih bisa memahami pikiran dan perasaannya sendiri hingga mampu menyadari bahwa kejadian yang dialaminya itu nyata. Hal ini berbeda dengan kondisi rumah partisipan NS. Di rumah, partisipan tidak boleh membahas tentang perasaannya. Partisipan juga merasa bahwa meskipun berada di rumah partisipan seperti tidak merasa di rumah. Hal ini menyebabkan partisipan merasa beku atau tidak merasakan apa apa sebagai respon terhadap trauma yang dialami. Partisipan bahkan menganggap bahwa yang dialaminya tidak benar dan hanya pasrah dengan apapun yang terjadi.

\section{Personal Growth}

Partisipan KR berpendapat bahwa kejadian ynag dialaminya berdampak pada potensi, minat, dan bakat yang dimiliki. Seringkali partisipan menerima pujian hanya karena fisiknya, sedangkan partisipan merasa bahwa masih ada hal lain seperti bakat dan potensi yang bisa dipuji selain fisiknya. Berdasarkan keterangan significant other partisipan KR, partisipan memiliki bakat dalam bidang seni. Namun partisipan cenderung mengikuti mood-nya untuk menghasilkan sesuatu. Justru kondisi saat partisipan sedang depresi adalah kondisi dimana gambar yang dihasilkan partisipan menjadi lebih bagus dari biasanya.

Partisipan NS juga memiliki minat dan bakat yang terus dikembangkan. Partisipan memiliki bakat dalam menulis dan mengasahnya dengan mengikuti lomba, penelitian dosen atau menjadi asisten dosen. Partisipan berpendapat bahwa dengan menulis dia merasa lebih dekat dengan dirinya. Menulis juga membantu partisipan untuk lebih memahami kejadian yang dialami hingga menyadari bahwa apa yang dialami memang suatu hal yang nyata.

Berbeda dengan partisipan KR, partisipan DD mengaku bahwa dirinya memiliki bakat dibidang olahraga. Partisipan masih melakukan hal-hal yang disukai asalkan menyenangkan. Beberapa cabang olahraga yang diminati adalah futsal, sepak bola, dan badminton. Partisipan pernah memenangkan beberapa turnamen lokal. Menurut partisipan VT, kejadian yang dialami partisipan tidak berpengaruh secara signifikan terhadap minat, bakat, dan potensi yang dimiliki partisipan. Namun kejadian tersebut sempat menyebabkan nilai partisipan menjadi turun. Partisipan juga malas untuk mengerjakan tugas dan bertemu dengan orang lain. Setelah mengalami kejadian pencurian dengan kekerasan, partisipan AP melakukan introspeksi diri mengapa kejadian tersebut bisa terjadi. Partisipan juga pernah dikucilkan karena sebagai laki-laki, dia dianggap tidak bisa menangani trauma yang dialami. Untuk 
minat dan bakat partisipan aktif mengikuti kegiatan yang menggunakan fisik seperti paskibra, futsal, dan bela diri.

\section{Positive Relation with Others}

Partisipan KR memiliki hubungan yang baik dengan teman-temannya. Partisipan tidak akan ragu untuk memutuskan hubungan dengan orang yang benar benar tidak dia sukai, tetapi partisipan akan tetap bersifat objektif ketika partisipan hanya membenci sifat seseorang dan bukan pribadi secara keseluruhan. Menurut partisipan NS, hubungannya dengan teman temannya terbilang baik karena partisipan NS sering diminta untuk membantu mereka. Partisipan juga tidak pernah menunjukkan kemarahan yang sering dirasakannya. Namun ketika temannya melakukan kesalahan partisipan langsung marah dan memutuskan hubungan dengan orang tersebut. Partisipan sengaja memutuskan hubungan dengan orang tersebut sebagai wujud hukuman atas perilaku yang dilakukan. Partisipan NS telah menyukai seseorang sejak semester 2. Partisipan NS merasa bahwa mungkin apa yang dirasakannya benar-benar cinta. Bahkan partisipan tidak marah ketika mengetahui bahwa orang yang disukai belum bisa membalas perasaannya. Hal ini berbeda dengan apa yang partisipan rasakan di lingkungan rumahnya. Partisipan berpendapat bahwa di lingkungan rumahnya, cinta, kasih, bersifat transaksional atau tukar menukar.

Setelah mengalami kejadian kekerasan seksual, Partisipan VT menyatakan bahwa dirinya menjadi takut dan lebih cuek terhadap orang yang tidak dikenal, terlebih apabila orang tersebut adalah laki laki. Hal ini berbeda dengan yang biasanya partisipan VT lakukan. Kejadian yang dialami partisipan VT juga berdampak pada kehidupan percintaannya. Partisipan sempat tidak mau bertemu dengan pacarnya selama beberapa waktu. Hubungan partisipan VT dengan keluarganya pernah menjadi canggung akibat kekerasan fisik yang diterimanya. Namun setelah itu, keadaan keluarganya menjadi baik seperti biasannya.

Hubungan partisipan DD dengan saudaranya tidak terlalu banyak terlibat interaksi karena memiliki perbedaan umur yang lumayan jauh. Partisipan DD menganggap bahwa dirinya peduli dengan teman walaupun tidak banyak bicara. Partisipan bukan merupakan tipe orang dengan banyak teman, melainkan orang dengan beberapa teman saja tapi memiliki hubungan yang baik. Partisipan juga bukan merupakan tipe orang yang mencari-cari teman untuk diajak main.

Menurut partisipan AP, setelah mengalami pencurian dengan kekerasan partisipan menjadi lebih sensitif terhadap benda kepemilikan dan kurang percaya dengan orang lain. Walaupun orang tersebut merupakan teman yang sudah sering berkumpul, apabila barang yang dipinjam merupakan barang yang berharga terlebih lagi yang meminjam adalah orang yang tidak dikenal, partisipan tidak akan meminjamkan. Namun, seiring karena saat ini partisipan sedang berada di asrama, pandangan tersebut mengalami perubahan. Hal ini disebabkan karena partisipan meyakini bahwa barang yang dipinjam masih dalam lingkup yang kecil dan tidak akan hilang.

\section{Purpose in Life}

Partisipan NS cukup rinci dalam memaparkan tujuan hidupnya atau hal-hal yang akan dilakukan pada tahap kehidupan selanjutnya. Mulai dari rencana untuk langsung bekerja setelah kuliah, membuat identitas baru, hingga karir kedepannya. Berbeda dengan tujuan hidup partisipan NS, tujuan hidup partisipan DD adalah masuk surga. Partisipan VT memandang bahwa setelah kejadian yang dialami, dia tidak boleh mengekang anaknya seperti yang dilakukan oleh orang tuanya. Ketika ditanya apa yang

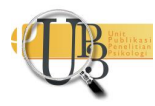


menjadi tujuan hidup, partisipan KR menjawab bahwa tujuan hidupnya adalah untuk membanggakan orang tuanya. Menurut significant other partisipan KR, partisipan hanya menjalani kehidupan saja tanpa adanya tujuan hidup yang jelas, karena alasan untuk bertahan hidup adalah orang tuanya. Menurut partisipan AP, kejadian yang dialaminya tidak berdampak akan tujuan hidupnya.

\section{Self-Acceptance}

Terkadang partisipan KR dan NS masih melakukan denial atas kejadian yang dialaminya. Partisipan NS menyatakan bahwa dirinya sedang berada di fase akan sembuh antara partisipan menyadari bahwa kejadian yang dialaminya benar terjadi atau kejadian tersebut tidak benar terjadi. Partisipan KR baru bisa menerima dirinya apabila sudah memenuhi tolak ukur keberhasilan yaitu membicarakan kejadian yang dialami kepada orang tuanya.

Partisipan NS juga mengatakan bahwa dirinya belum bisa menerima diri sendiri. Partisipan mengatakan bahwa apabila bisa ditukar, partisipan ingin menukar kelebihan yang dia miliki dengan kecantikan. Partisipan meyakini akan lebih mudah mendapatkan apa yang dia mau dan orang lain akan lebih mudah bersimpati terhadap apa yang dialaminya.

Dahulu setelah mengalami kekerasan seksual, partisipan VT berusaha menenangkan diri dan berkata bahwa ini bukan salahnya. Disisi lain, partisipan masih bertanya tanya mengapa harus partisipan VT yang menjadi korbanya. Seiring berjalannya waktu partisipan merasa pasrah dengan apa yang sudah terjadi karena tidak bisa diubah juga. Setelah kejadian pencurian dengan kekerasan dialami oleh partisipan AP, partisipan melihat dirinya sebagai orang yang cupu karena tidak bisa melawan dan mempertahankan hak miliknya. Namun, partisipan AP sudah lebih protektif terhadap barang yang dimiliki. Partisipan juga menilai bahwa menjadi sensitif terhadap kepemilikan barang merupakan hal yang baik karena akan membentuk tanggung jawab dari orang lain. Partisipan DD menerima kejadian yang dilalui dan pemeberian apapun. Menurut partisipan tugas kita adalah menjaga pemberian tersebut.

\section{I S K U S I}

Saat mengalami kejadian traumatis, beberapa partisipan mengalami respon freezing. Freezing adalah respon yang dihasilkan apabila respon fight or flight tidak memungkinkan untuk dilakukan (Brand \& Frewen, 2017). Saat terjadi respon ini, tubuh menjadi kaku dan tidak bisa melakukan apa-apa. Beberapa partisipan menjadi blank selama beberapa detik sebelum melakukan respon yang sebenarnya ingin mereka lakukan. Partisipan NS mengaku shock dengan tindakan pencurian dengan kekerasan yang dialaminya, saat itu partisipan juga bertanya tanya apakah kejadian yang dialaminya merupakan suatu hal yang nyata atau tidak. Seorang partisipan beberapa kali meragukan kejadian traumatis yang dialaminya dan menganggap bahwa kejadian itu tidak nyata karena merasa bahwa tidak wajar orang seperti dia mengalami hal tersebut. Selain itu, respon anggota keluarga partisipan terhadap apa yang dialaminya juga memperkuat pikiran partisipan bahwa apa yang dialaminya bukanlah hal yang nyata. Adanya perasaan bahwa sesuatu yang nyata terjadi menjadi tidak nyata disebut juga dengan derealisation. Derealisation adalah salah satu gejala gangguan dissociative yang merupakan fenomena yang berkaitan dengan trauma (Brand \& Frewen, 2017). Beberapa partisipan merubah kebiasaannya sejalan dengan perubahan pandangan dan pemaknaan akibat kejadian traumatis yang dialaminya. Hal ini sesuai dengan penelitian (Aldwin, 2007) bahwa makna yang diberikan individu pada pengalaman stres dan traumatis mereka menentukan bagaimana mereka menanggapinya (Aldwin, 2007). 
Berkaitan dengan dimensi autonomy, makna kejadian yang dialami partisipan akan menentukan bagaimana partisipan menilai dirinya sendiri. Kedua partisipan dalam penelitian ini cenderung pasrah atau hopeless dengan apa yang terjadi kepada mereka setelah mengalami kejadian traumatis. Sebelunya banyak omongan negatif yang dilontarkan kepada kedua partisipan, namun mereka sudah tidak memikirkan lagi omongan negatif tersebut. Mereka cenderung membiarkan semuanya terjadi bagaimana adanya dan tidak berusaha untuk mengubah pandangan orang lain terhadap mereka menjadi lebih baik. Hal ini berbeda dengan partisipan lain, yang menghindari untuk menceritakan kejadian yang dialami karena takut dipandang negatif oleh orang lain.

Pada dimensi self-acceptance, partisipan yang merupakan korban kekerasan seksual ataupun fisik cenderung tidak secara gamblang menyatakan bahwa dia menerima dirinya seutuhnya. Hal ini sangat berbeda dengan kedua korban pencurian dengan kekerasan yang menyatakan secara tegas bahwa dia sudah bisa menerima dirinya dan kejadian traumatis yang dialami. Partisipan yang merupakan seorang korban kekerasan seksual, bukannya menghindari stressor atau hal-hal terkait traumanya, tetapi justru semakin banyak melakukan kegiatan serupa. Hal ini dikenal dengan istilah re-enactment. Re-enactment adalah mengalami kembali trauma yang dialami dalam berbagai cara (Substance Abuse and Mental Health Services Administration, 2014). Beberapa hal diantaranya adalah perilaku melukai diri sendiri, hiperseksualitas, berjalan sendirian di area yang tidak aman atau perilaku berisiko tinggi lainnya, mengemudi sembarangan, atau terlibat dalam hubungan destruktif yang berulang. Hal ini sejalan dengan penelitian (Littleton et al., 2014) yang berpendapat bahwa perilaku seksual yang beresiko pada individu yang beranjak dapat diprediksi melalui riwayat kekerasan seksual yang dialaminya pada masa anak-anak dan beranjak dewasa. Adanya gejala depresi berhubungan kuat dengan penggunaan kegiatan seksual sebagai strategi untuk meregulasi trauma akibat kekerasan seksual. Selain itu, partisipan juga melakukan tindakan menyakiti diri sendiri seperti cutting serta adanya keinginan untuk bunuh diri. Peneliti menduga partisipan KR mungkin mengembangkan trauma yang dialami menjadi masalah kesehatan mental yang lebih serius yaitu depresi, namun belum ada asesmen lanjutan dan diagnosis yang ditetapkan.

Pada dimensi positive relation with others, berdasarkan psychological well-being (Ryff \& Singer, 1996) seseorang yang berfungsi dengan baik memiliki rasa empati dan afeksi yang tinggi terhadap orang di sekitarnya. Memiliki hubungan yang hangat merupakan wujud kedewasaan. beberapa partisipan menyatakan bahwa kejadian tersebut berdampak negatif pada hubungan mereka dengan orang lain. sempat menarik diri dari lingkungan sosialnya selama kurang lebih dua bulan dan tidak ingin. Disisi lain, kekerasan yang dilakukan oleh keluarga korban tidak dapat disamakan dengan dengan kekerasan seksual yang dialami oleh mereka. Partisipan menyatakan bahwa walaupun mereka pernah mengalami kejadian itu, kejadaian itu tidak terlalu berdampak dengan kehidupan mereka lagi. Karena partisipan sudah mampu memahami sepenuhnya kejadian yang dialami dan berdamai dengan anggota keluarga sehingga tidak ada rasa dendam.

Dalam dimensi purpose in life, dan personal growth sebagian besar partisipan sudah memahami tujuan hidupnya dan bagaimana cara mengembangkan potensi dirinya. Kejadian traumatis yang dialami tidak terlalu mempengaruhi bagaimana partisipan memanfaatkan bakat dan potensinya, walaupun salah satu partisipan bisa merasakan pengaruh jangka pendeknya seperti nilai yang turun, namun partisipan sudah mampu bangkit dari kondisi tersebut dan berfungsi lebih baik. Bisa jadi, minat dan bakat yang dikembangkan partisipan merupakan faktor protektif dari trauma yang dialaminya seperti yang dialami dua partisipan dalam penelitian ini.

Di antara semua partisipan yang melakukan wawancara, partisipan dengan riwayat pencurian dengan kekerasan adalah pihak dengan dampak paling ringan. Hal ini dikarenakan kejadian yang dialami sudah 
terjadi cukup lama melihat kedua partisipan tersebut sudah mengalami kejadian lebih dari 4 tahun yang lalu. Kedua partisipan tersebut juga berjenis kelamin laki-laki. Hal ini sangat berbeda dengan kejadian yang dialami partisipan korban kekerasan yang beru terjadi beberapa bulan yang lalu. Pada partisipan korban kekerasan seksual, dapat dengan jelas terlihat dampak dari kejadian traumatis yang dialami. Kedua partisipan tersebut memiliki riwayat kejadian traumatis lebih dari satu. Bahkan partisipan NS mengalami luka yang cukup parah akibat kejadian yang dialaminya.

Secara garis besar, kejadian traumatis yang dialami seorang individu akan berdampak kepada psychological well-being individu. Namun tidak semuanya mengarah kepada hal negatif karena individu memiliki kesempatan untuk beradaptasi terhadap kejadian yang dialami. Pada tahap perkembangan ini juga, individu memiliki otonomi diri serta kesempatan untuk mengatur tujuan hidup yang lebih luas dibandingkan tahap perkembangan sebelumnya. Walaupun diantaranya masih dalam proses penyembuhan dan penerimaan diri yang didasari oleh kedewasaan, tanggung jawab, dan keyakinan bahwa trauma yang dialami berada diluar kendalinya, beberapa individu lainnya akhirnya berhasil untuk beradaptasi dan menerima dari kejadian yang dialami.

Keterbatasan dalam penelitian ini yang pertama adalah kurangnya data statistik kejadian yang berpotensi traumatis di Indonesia. Oleh sebab itu, peneliti sebagian besar menggunakan jurnal dari luar negeri. Dengan adanya perbedaan budaya memungkinkan adanya perbedaan pada prevalensi kejadian traumatis pada individu beranjak dewasa yang sebenarnya. Selain itu peneliti juga tidak menggunakan alat ukur kualitatif untuk mengukur tingkat psychological well-being Korban pasca kejahatan dan kekerasan. Oleh sebab itu, peneliti tidak bisa menentukan tinggi rendahnya psychological well-being partisipan penelitian ini. Data yang dihasilkan bersifat deskriptif dan dipaparkan dalam bentuk narasi dan dirangkum dalam matriks hasil penelitian. Keterbatasan yang terakhir adalah adanya pandemi COVID-19 yang menyebabkan pembatasan sosial. Sebagai bentuk penjagaan diri, wawancara dilakukan secara daring. Oleh sebab itu data observasi yang dimiliki tidak banyak dan memaksimalkan data yang diperoleh melalui significant others.

\section{S I M P U L A N}

Berdasarkan hasil penelitian mengenai psychological well-being korban pasca traumatic event kejahatan dengan kekerasan, dapat diambil kesimpulan bahwa masing-masing subjek memiliki dimensi dalam psychological well-being yang terdampak sebagai respon dari kejadian traumatis yang dialaminya. Namun, beberapa subjek juga sudah menjadi lebih adaptif terhadap perubahan-perubahan yang diakibatkan oleh kejadian traumatis tersebut. Disisi lain, ditemukan bahwa pada beberapa subjek, dimensi Personal growth bisa berperan sebagai faktor protektif mereka. Sebagian besar subjek tidak menunjukkan gejala gangguan kesehatan mental yang lebih serius seperti PTSD selain mengalami kejadian traumatis. Namun, diantaranya menunjukkan gejala dissociative, yaitu derealisation dan yang lainnya mengalami gejala depresi seperti adanya keinginan untuk bunuh diri dan menyakiti diri sendiri.

\section{U CAPAN TERIMA KASIH}

Terima kasih kepada Ibu Nurul Hartini, Ibu Endang R. Surjaningrum, dan Ibu Ika Yuniar Cahyanti yang telah membimbing saya hingga tahap ini. Juga kepada kedua orang tua dan keluarga saya yang telah merawat dan menyayangi saya hingga menjadi pribadi seperti ini. 


\section{DEKLARASI POTENSI TERJADINYAKONFLIK KEPENTINGAN}

Latieva Sonia Salmany dan Nurul Hartini tidak bekerja, menjadi konsultan, memiliki saham, atau menerima dana dari perusahaan atau organisasi manapun yang mungkin akan mengambil untung dari diterbitkannya naskah ini.

\section{P US T AKA A C UA N}

Aldwin, C. M. (2007). Stress, Coping and Development; An Intergrative Perspective. In E. E. Werner (Ed.), Library of Congress Cataloging-in-Publication Data. The Guilford Press.

Allen, J. (2001). Post-traumatic depression. In Traumatic relationships and serious mental disorders.

American Psychiatric Association. (2013). DSM-5 Diagnostic Classification. In Diagnostic and Statistical Manual of Mental Disorders. https://doi.org/10.1176/appi.books.9780890425596.x00diagnosticclassification

Astuti, I. S. Y. (2016). Interaksi Sosial Korban Perkosaan Di Kabupaten Tuban (Studi kasus stigma negatif dan diskriminasi masyarakat Kepada korban perkosaan). Fakultas Ilmu Sosial Dan Ilmu Politik Universitas Airlangga, 23.

Bowker, L. H., Bogdan, R., \& Taylor, S. J. (1978). Introduction to Qualitative Research Methods: A Phenomenological Approach to the Social Sciences. Teaching Sociology. https://doi.org/10.2307/1317067

Brand, B. L., \& Frewen, P. (2017). Dissociation as a trauma-related phenomenon. In APA handbook of trauma psychology: Foundations in knowledge (Vol. 1). https://doi.org/10.1037/0000019-013

Creamer, M., Burgess, P., Buckingham, W., \& Pattison, P. (1993). Posttrauma reactions following a multiple shooting: A retrospective study and methodological inquiry. In International handbook of traumatic stress syndromes. https://doi.org/10.1007/978-1-4615-2820-3_17

Galatzer-Levy, I. R., Burton, C. L., \& Bonanno, G. A. (2012). Coping flexibility, potentially traumatic life events, and resilience: A prospective study of college student adjustment. Journal of Social and Clinical Psychology. https://doi.org/10.1521/jscp.2012.31.6.542

Gunawan, I. (2014). Metode Penelitian Kualitatif: Teori dan Praktik. In Jakarta: Bumi Aksara.

Hamidah, H., Hartini, N., \& Suryanto, S. (2018). Risk Factors of Post Traumatic Stress Disorder in Child Sexual Abuse Victims. Journal of Educational, Health and Community Psychology, 7(August), 179196.

Hanggoro, Y. (2015). Penelitian deskriptif: Subjective well-being pada biarawati di Yogyakarta (Issue 099114114). https://repository.usd.ac.id/688/2/099114114_full.pdf.

Huppert, F. A. (2009). Psychological Well-being: Evidence Regarding its Causes and Consequences. Applied Psychology: Health and Well-Being. https://doi.org/10.1111/j.1758-0854.2009.01008.x

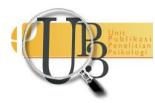


Kementrian Pemberdayaan Perempuan dan Perlindungan Anak. (2020). Kemen PPPA: Korban Kekerasan Banyak Yang Tidak Mau Melapor. Publikasi Media Kementerian Pemberdayaan Perempuan Dan Perlindungan Anak. https://www.kemenpppa.go.id/index.php/page/read/29/2846/kemen-pppa-korbankekerasan-banyak-yang-tidak-mau-melapor

KUHP RI. (1992). Kitab Undang-Undang Hukum Pidana (KUHP) RI INDONESIA. Buku 2 Kejahatan.

Littleton, H. L., Grills, A. E., \& Drum, K. B. (2014). Predicting risky sexual behavior in emerging adulthood: Examination of a moderated mediation model among child sexual abuse and adult sexual assault victims. Violence and Victims. https://doi.org/10.1891/0886-6708.VV-D-13-00067

Machado, L., Reis de Oliveira, I., Peregrino, A., \& Cantilino, A. (2019). Common mental disorders and subjective well-being: Emotional training among medical students based on positive psychology. PLoS ONE. https://doi.org/10.1371/journal.pone.0211926

Macleod, K. B., \& Brownlie, E. B. (2014). Mental health and transitions from adolescence to emerging adulthood: Developmental and diversity considerations. Canadian Journal of Community Mental Health. https://doi.org/10.7870/cjcmh-2014-007

Miles, M. B., \& Huberman, M. (1994). Qualitative Data Analysis Second Edition. In SAGE Publications.

Nathania, F., Husna, N., Selvia, A., Kevin, L., Audrey, C., \& Hutapea, B. (2017). Analisis Gambaran Subjective Well-Being Korban Kejahatan Pencurian Dan Penculikan. Intuisi : Jurnal Psikologi Ilmiah, 9(3), 196-209.

Overstreet, C., Berenz, E. C., Sheerin, C., Amstadter, A. B., Canino, G., \& Silberg, J. (2016). Potentially traumatic events, posttraumatic stress disorder, and depression among adults in Puerto Rico. Frontiers in Psychology. https://doi.org/10.3389/fpsyg.2016.00469

Park, C. L., \& Gutierrez, I. A. (2013). Global and situational meanings in the context of trauma: Relations with psychological well-being. Counselling Psychology Quarterly. https://doi.org/10.1080/09515070.2012.727547

Park, C. L., Mills, M. A., \& Edmondson, D. (2012). PTSD as meaning violation: Testing a cognitive worldview perspective. Psychological Trauma: Theory, Research, Practice, and Policy. https://doi.org/10.1037/a0018792

Poerwandari, E. K. (2007). Pendekatan Kualitatif: Penelitian Perilaku Manusia. Depok: Lembaga Pengembangan Sarana Pengukuran Dan Pendidikan Psikologi (LPSP3), Fakultas Psikologi UI.

Ridder, H. G., Miles, M. B., Michael Huberman, A., \& Saldaña, J. (2014). Qualitative data analysis. A methods Sourcebook. Zeitschrift Fur Personalforschung. https://doi.org/10.1177/239700221402800402

Riggs, S. A., \& Han, G. (2009). Predictors of anxiety and depression in emerging adulthood. Journal of Adult Development. https://doi.org/10.1007/s10804-009-9051-5

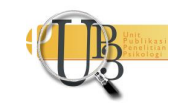


Runturambi, A. J. S. (2017). Makna Kejahatan dan Perilaku Menyimpang dalam. 2, 125-135.

Ryff, C. D., \& Singer, B. (1996). Psychological well-being: Meaning, measurement, and implications for psychotherapy research. Psychotherapy and Psychosomatics. https://doi.org/10.1159/000289026

Schmitt, M. T., Postmes, T., Branscombe, N. R., \& Garcia, A. (2014). The consequences of perceived discrimination for psychological well-being: A meta-analytic review. Psychological Bulletin. https://doi.org/10.1037/a0035754

Statistik, B. P. (2019). Cover statistik kriminal 2019. Cover Statistik Kriminal 2019.

Substance Abuse and Mental Health Services Administration. (2014). Trauma-Informed Care in Behavioral Health Services. In Journal of the Canadian Academy of Child and Adolescent Psychiatry.

Ursano, R. J. (2012). Post-traumatic stress disorder and other trauma disorders. In Maryland medicine: MM : a publication of MEDCHI, the Maryland State Medical Society (Vol. 13, Issue 3, pp. 13-14). Wits University Press.

Willig, C. (2013). Introducing Qualitative Research in Psychology Third Edition. Handbook of Qualitative Research. 